\title{
BLOCKING EFFECT OF DESMETHYLIMIPRAMINE ON DOPAMINE-INDUCED SINUS ACCELERATION
}

\author{
Shigetoshi CHIBA, Kazuhiko IWATSUKI and Hiroshi ONO \\ Department of Pharmacology, Tohoku University School of Medicine, Sendai, Japan
}

Accepted February 27, 1974

Although dopamine is the precursor of norepinephrine, exogenous dopamine exerts cardiac effects both by acting directly on beta-adrenergic receptors and by releasing norepinephrine from sympathetic storage sites as a "mixed amine" classified by Goldberg (1). When dopamine was injected into the sinus node artery (Rolett and Black (2); Chiba et al. (3)), the duration of dopamine-induced sinus acceleration was short at lower doses but became much longer with larger doses, while either norepinephrine- or epinephrine-induced sinus acceleration was short duration with every dose tested. Thus we assumed that dopamine has predominant indirect action when injected into the sinus node artery (3). In the present study, we tried to investigate whether or not dopamine is modified by desmethylimipramine (DMI) or tetrodotoxin, using a direct perfusion technique of the sinus node artery of the dog (Hashimoto et al. (4)).

Seven mongrel dogs weighing 10 to $17 \mathrm{~kg}$ were anesthetized with intravenous sodium pentobarbital $(30 \mathrm{mg} / \mathrm{kg})$ and artificial respiration was maintained. All animals were bilaterally vagotomized. The chest was opened through the right 4th intercostal space and the heart was kept in its original position by making a pericardial cradle. The sinus node artery was cannulated and perfused under a constant pressure at $100 \mathrm{~mm} \mathrm{Hg}$. When dopamine, 0.1 to $1 / \mathrm{gg}$, was injected into the sinus node artery, sinus acceleration was usually induced. The dopamine-induced sinus acceleration was completely blocked by 1 to $10 \mu \mathrm{g}$ of propranolol. And it was markedly suppressed by 10 to 30 /g of DMI as shown in Fig. 1, but not by 1 to $3 / g$ of tetrodotoxin. Blocking effects of DMI are summarized in table 1.

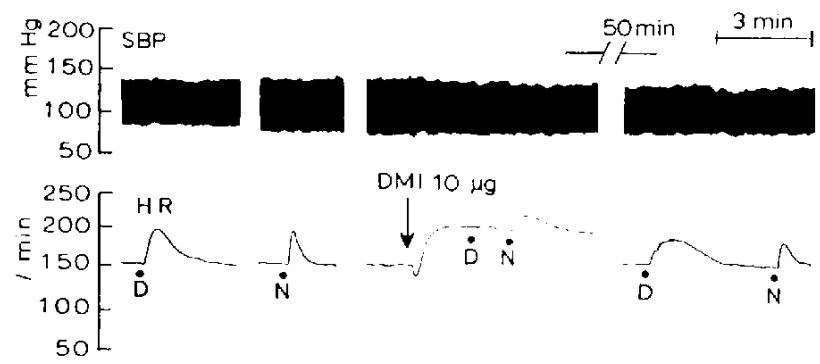

FIG. 1. Effect 'of $10 \mu \mathrm{g}$ of desmethylimipramine (DMI) on positive chronotropic responses to $1 / \mathrm{gg}$ of dopamine (D) and $0.1 \mathrm{\mu g}$ of norepinephrine (N). SBP, systemic blood pressure: HR, heart rate. 
TABLE 1. Effect of desmethylimipramine on dopamine- and norepincphrine-induced positive chronotropic responses.

\begin{tabular}{|c|c|c|c|c|c|c|c|c|c|}
\hline \multirow{3}{*}{$\begin{array}{l}\text { Dose of } \\
\text { compounds }\end{array}$} & \multicolumn{9}{|c|}{ Desmethylimipramine treatment $(10$ to $30 \mathrm{mg})$} \\
\hline & \multicolumn{3}{|c|}{ Bcfore } & \multicolumn{3}{|c|}{ After 1 to $3 \mathrm{~min}$} & \multicolumn{3}{|c|}{ After 60 to $90 \mathrm{~min}$} \\
\hline & $\begin{array}{l}\text { Initial } \\
\text { HR } \\
\text { (beats } \\
\text { min) }\end{array} \mid$ & $\begin{array}{l}\text { Maximum } \\
\text { HR } \\
\text { (bcatsi } \\
\text { min) }\end{array}$ & $\mathrm{JHR} *$ & $\begin{array}{l}\text { Initial } \\
\text { HR } \\
\text { (beats/: } \\
\text { min) }\end{array}$ & $\begin{array}{l}\text { Maximum } \\
\text { HR } \\
\text { (beats/ } \\
\text { min) }\end{array}$ & $\Delta \mathrm{HR}^{*}$ & $\begin{array}{l}\text { Initial } \\
\text { HR } \\
\text { (beats } \\
\text { min) }\end{array}$ & $\begin{array}{c}\text { Maximum } \\
\text { (beats } \\
\text { min) }\end{array}$ & $\Delta \mathrm{HR}^{*}$ \\
\hline $\begin{array}{c}\text { Dopamine } \\
1-3 / 4 \mathrm{~g}\end{array}$ & 13919.0 & $189 \perp 4.6$ & $50 \div 4.9$ & $173: 6.0$ & $180 ! 4.5$ & $7 ! 1.9$ & $139: 9.0$ & $170 \pm 10$ & $31 \div 7.9$ \\
\hline $\begin{array}{l}\text { Norepine- } \\
\text { phrine } \\
0.10 .3 \mu \mathrm{g}\end{array}$ & $139 \div 9.0$ & $172 . \pm 8.5$ & $33: 8.3$ & $173 \therefore 6.2$ & $198+2$ & $25: 4.3$ & $139+9.0$ & $170+8.8$ & $31 \div 8.3$ \\
\hline
\end{tabular}

* Defferences (Maximum HR-Initial HR).

All values are given in mean S.E.M. in 5 experiments.

It is well known that DMI inhibits the action of tyramine by blocking the uptake mechanism at the adrenergic nerve terminal. On the other hand, tetrodotoxin suppresses the nerve excitation but it does not inhibit tyramine action on the SA node as reported previously (Hashimoto and Chiba (5)). In the present study, it is suggested that the action of dopamine is tyramine-like mainly due to release of norepinephrine. In 1937, Gurd (6) described that dopamine increased contraction of the heart, and that this action was attenuated, but not blocked, by cocaine. Recently, it was demonstrated that the positive inotropic and chronotropic actions of dopamine were reduced or not potentiated by cocaine, desipramine and reserpine pretreatment (Farmer (7); Tsai et al. (8); Tuttle (9)). In the dog heart, the action of dopamine differs from those of other catecholamines, because it causes a smaller increase in heart rate at an equivalent increment in cardiac contractile force (Harrison et al. (10); McDonald and Goldberg (11); Wintroub et al. (12)). The disparity between heart rate and contractility may be due to a small direct effect of dopamine on the SA node.

\section{REFERENCES}

1) Goldberg, L.I. : Pharmacol. Rov. 24, 1 (1972); 2) Rolett, L.L. and Bi.Ack, W.L. : Circlilation 34, (Suppl), ll-200 (1966): 3) Chiba, S., Hashmoto, H. anid Hashimoto, K. : Japan. J. Pharmacol. 23, 329 (1973); 4) Hashimoto, K., Tanaka, S., Hirata, M. and Chlba, S. : Circllation Res. 21, 297 (1967); 5) HAsumoto, K. AND CHibs, S.: J. Pharmacel. exp. Ther. 170, 91 (1969); 6) Gurd, M.R.: Quart. J. Pharm. Pharmacol. 10, 188 (1937); 7) Farmer, J.B.: J.

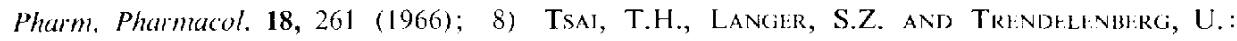
J. Pharmacol. exp. Ther. 156, 310 (1967); 9) TutTlı, R.R.: Pharmacologiti 12, 213 (1970); 10) Harrisoy, D.C., Piragis, S., Robison, S.C. and Wintroub, B.U.: Br. I. Pharmacol. (hemother. 37, 618 (1969); 11) Mcoonald, R.H., Jr. AND Goldblig, L.I. : I. Pharmacol. exp. Ther. 140, 60 (1963); 12) Wintroub, B.U., Schroeder, J.S., Schroll, M., Robison, S.L. ANd Harrison, D.C.: Am. J. Physiol. 217, 1716 (1969). 